Gut, 1972, 13, 341-345

\title{
The role of the sympathetic nervous system in hypoglycaemia-stimulated gastric secretion
}

\author{
A. J. HODGE, J. R. MASAREI, AND B. N. CATCHPOLE \\ From the Department of Surgery, University of Western Australia, Royal Perth Hospital
}

SUMMARY The gastric secretory response to insulin is mediated predominantly by the vagus. The associated hypoglycaemia stress response is mediated by the sympathetic nervous system.

Inhibition of the sympathetic response by simultaneous alpha and beta receptor blockade was studied in five healthy young adults.

No appreciable modification of gastric secretory output resulted.

Insulin-induced hypoglycaemia leads to vagally mediated stimulation of gastric secretion (Hollander, 1946). Insulin-induced hypoglycaemia also produces a stress response mediated by the sympathetic nervous system (Cannon, McIver, and Bliss, 1924; von Euler and Luft, 1952; Duner, 1954; Cantu, Wise, Goldfien, Gullixson, Fischer, and Ganong, 1963). Adrenaline and 1-noradrenaline reduce basal and stimulated gastric secretion (Baronofsky and Wangensteen, 1945; Forrest and Code, 1954; Leonsins and Waddell, 1958; Nicoloff, Peter, Stone, and Wangensteen, 1964; Haigh, Moffitt, and Steedman, 1967). It appears therefore that the effects on secretion of the parasympathetic and sympathetic nervous systems are mutually antagonistic.

This study was undertaken to determine whether inhibition of the sympathetic component leads to a rise in human secretion during insulin-induced hypoglycaemia. In order to achieve adequate inhibition of this sympathetic component it is necessary to block specifically both alpha and beta sympathetic receptors (Ahlquist, 1948) simultaneously, and this was done.

\section{Methods and Materials}

Five healthy informed volunteers between the ages of 20 and 26 years each underwent two studies in random order. The intervals between studies were seven, 12, 14, 38, and 54 days. An electrocardiogram was performed on all subjects before the experiments to exclude the presence of any cardiac conduction defects.

Received for publication 25 January 1972.
CONTROL INSULIN STUDY

After a 12-hour fast from nine o'clock the previous evening a 14FG gastric tube was passed into the stomach and the opaque tube tip fluoroscopically positioned so that it lay in the most dependent part of the stomach with the subject lying on his lefthand side.

Following four 15-minute basal collections of gastric secretion, aspiration being performed continuously by hand, an intravenous infusion of $0.9 \%$ saline was set up and continued for the remainder of the experiment. The total volume infused did not exceed 1 litre.

Thirty minutes after beginning this infusion, the stomach was aspirated and the specimen discarded. Crystalline insulin ${ }^{1}, 0 \cdot 15$ units per kilogram body weight, was then injected intravenously as a bolus, and eight further 15-minute gastric samples were obtained.

Blood sugar levels were measured before and after the basal collection, immediately before giving the insulin, and afterwards, at 15, 30, 45, 75, and 105 minutes. Blood pressure and pulse rate were recorded at 15-minute intervals throughout, and more often when indicated.

INSULIN STUDY WITH SYMPATHETIC BLOCKADE A similar procedure to that described above was followed with the exception that the infusion contained phentolamine ${ }^{2}, 0.5 \mathrm{mg}$ per $\mathrm{ml}$. A loading injection of $10 \mathrm{mg}$ phentolamine was first given intravenously and then the infusion run in at the rate of $2 \mathrm{ml}$ per minute. Alpha receptor blockade ${ }^{1}$ Insulin BP 20 units per ml (CSL Australia) glucagon less than 0.69\% 'Phentolamine mesylate (Regitine $\mathbb{R}$, Ciba, Australia) 
was indicated by a consistent rise in pulse rate of 20 beats per minute, usually accompanied by a fall in diastolic blood pressure. Once achieved, the infusion rate was adjusted to maintain this steady state. Blockade was always achieved within $\mathbf{3 0}$ minutes of commencement of the phentolamine and then maintained for a further 75 to 120 minutes. A total of $120 \mathrm{mg}$ phentolamine was not exceeded in any experiment.

When a steady state of alpha blockade was achieved, propranolol ${ }^{3}$ was given intravenously, not more rapidly than $1 \mathrm{mg}$ per minute, until the pulse rate returned to basal levels while the phentolamine continued to run at a blocking dose rate. This required a dosage of 4 to $8 \mathrm{mg}$ of propranolol.

We found this procedure safe in every case. There were no after effects, although during the period of alpha blockade nasal congestion was uncomfortable.

On each gastric sample, volume was measured directly by volumetric cylinder, $p \mathrm{H}$ by glass electrode, and titratable acidity by the addition of $\mathrm{N} / 10 \mathrm{NaOH}$ to an electrode $p \mathrm{H}$ of $7 \cdot 40$.

Blood sugar levels were measured by an AutoAnalyzer using the ferricyanide method (Technicon Methodology N2A) on blood obtained by repeated venepuncture.

\section{Results}

Figure 1 presents the mean blood sugar estimations, with standard errors, during the 'insulin only' and

'Propranolol hydrochloride (Inderal $§$, ICI Australia) the 'insulin plus alpha and beta blockade' studies. Although it has been reported that beta receptor blockade delays the return of the blood sugar level towards normal following insulin (Abramson, Arky, and Woeber, 1966) this was not seen with both alpha and beta receptor blockade (Fig. 1).

The mean values of the acid outputs with standard errors were calculated for the five subjects and are presented in Figure 2. Using paired Student's t tests there was no significant effect on any of the 15minute outputs after insulin nor on total 120-minute outputs. There were no significant differences in volume outputs nor acid concentrations using the same statistical procedure.

Peak acid output, calculated as maximum acid output in any two consecutive 15-minute periods, fell as a result of sympathetic blockade in all subjects but one $(M=17 \cdot 1 \pm S E 1 \cdot 60$ to $M=14.0 \pm S E$ 0.77). However, significance was not achieved when paired Student's $t$ test was applied $(0 \cdot 20>P>0 \cdot 10)$.

During the study, changes in blood pressure (with limits of $\pm 20 \mathrm{~mm} \mathrm{Hg}$ systolic and $\pm 20 \mathrm{~mm} \mathrm{Hg}$ diastolic) as a result of experimental manipulations and sympathetic blockade could not be correlated with any changes in gastric secretion. Similarly alterations in pulse rate (with limits of \pm 25 beats per minute) could not be shown to be related to secretion.

\section{Discussion}

In all subjects there was evidence of both a parasympathetic and sympathetic nervous response when

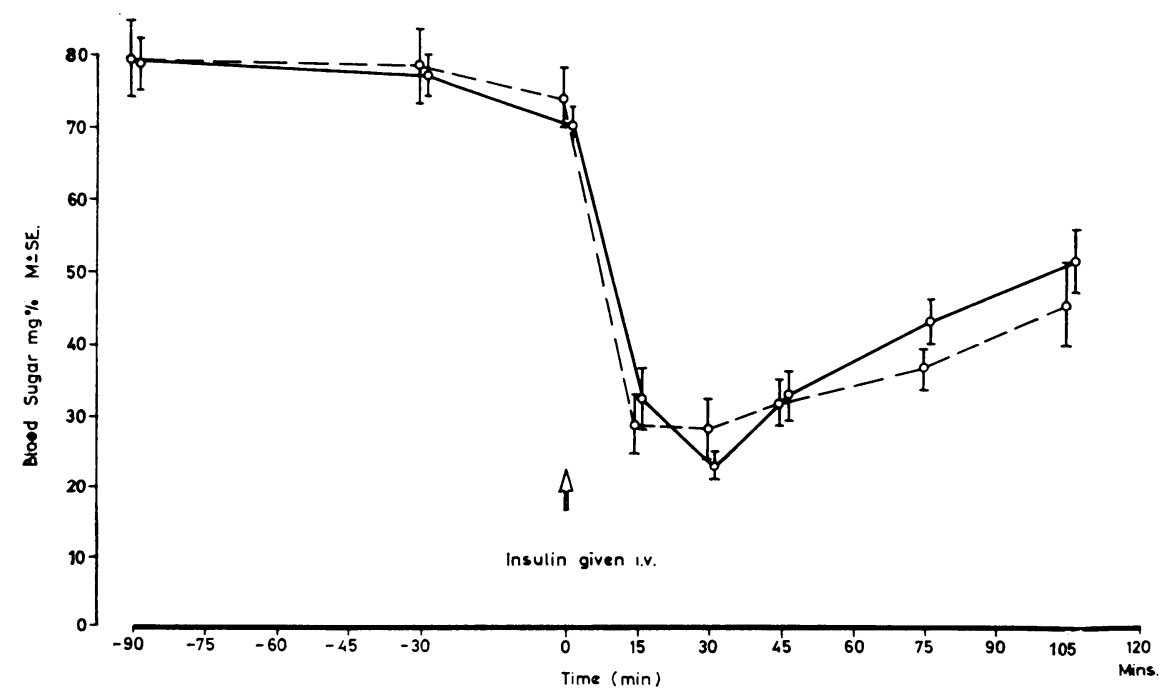

Fig. 1 Blood sugar level before and after giving insulin. - - without blockade, with blockade. There is no significant difference between the two curves using paired t tests. 


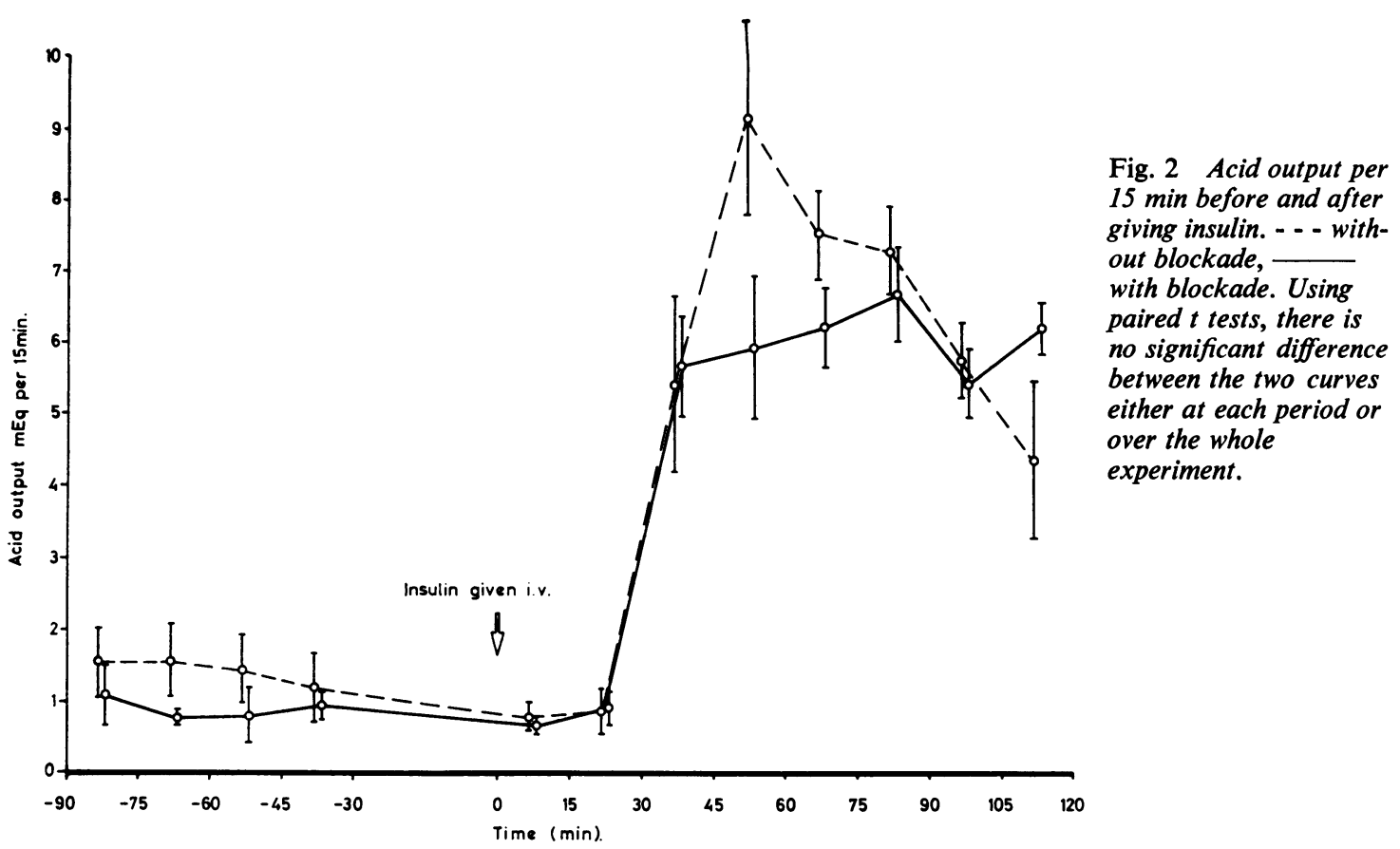

blood sugar was appropriately lowered. The rise of gastric secretion indicated the expected parasympathetic response (Fig. 2). The sympathetic nervous response was demonstrated clinically by sweating, palpitation, tachycardia, and a feeling of anxiety by the subject. However, the sympathetic alpha and beta receptor blockade appeared adequate as indicated by the sequential cardiovascular effects.

Although it is believed that there is initial inhibition of gastric secretion by insulin (Olsen and Necheles, 1955; Geziri, Robertson, Plzak, and Woodward, 1958; Hirschowitz and Robbins, 1966; Schapiro, Cummins, and Wruble, 1967; Singleton, 1969), we obtained no significant statistical evidence to support them (Fig. 2).

It was expected that when the sympathetic component of the stress response to insulin was removed in this study, gastric secretion would increase. However, this occurred in only two experiments. It is probably safe to conclude that the effects of the sympathetic nervous system on the vagally driven acid output of hypoglycaemia are of little consequence. The reasons for this can only be speculative.

There seem to be two possibilities. In the first place there seems to be no information available regarding the direct effects of catecholamines on the parietal cell, nor is there any on the effects of phentolamine and propranolol. What effect therefore these agents had in this study is unknown. In the second place, however, there is some information on the indirect effects of catecholamines on gastric secretion.

Many published reports have indicated that during basal secretion and many varying types of secretory stimulation, catecholamines have an inhibiting effect (Baronofsky and Wangensteen, 1945; Forrest and Code, 1945b; Leonsins and Waddell, 1958; Nicoloff et al, 1964; Haigh et al, 1967). However Linde (1950), Code (1951), and Karvinen and Karvonen (1953) found them to have no effect. Haigh and Steedman (1968) found inconstant effects while Cumming, Haigh, Harries, and Nutt (1963) believe that they stimulate secretion. These apparently conflicting results may be due to variations induced in mucosal blood flow.

Cutting, Dodds, Noble, and Williams (1937) showed that the effect of parietal cell stimulation is dependent on adequate gastric blood flow, but it has been realized more recently (Thompson and Vane, 1953; Nicoloff et al, 1964; Delaney and Grim, 1965; Jacobson, Swan, and Grossman, 1967) that the significant part of gastric blood flow is that to the mucosa. During histamine stimulation total gastric blood flow may be increased with adrenaline by the opening of subserosal and submucosal arteriovenous shunts while simultaneously causing mucosal vasoconstriction; this leads to a fall in secretion (Peters and Womack, 1958; Nicoloff et al, 1964). Also, the infusion of catecholamines into the arterial supply of the stomach produces patchy mucosal congestion 
and ulceration (Baronofsky and Wangensteen, 1945; Stokes, 1971). However, vagal tone appears to be important in maintaining gastric mucosal blood flow since Bell and Battersby (1968) found a significant decrease of blood flow in the canine gastric mucosa after vagotomy.

Enhanced sympathetic nervous activity may depress gastric parietal cell secretion directly, reduce it by diminishing mucosal blood flow, or have both these actions. Whatever the mechanisms involved, this study indicates that the vagal dominance of hypoglycaemia overwhelms them since their removal by sympathetic nervous blockade is without effect.

A scheme of possible influences on the gastric parietal cell following exogenous insulin is presented in Figure 3.

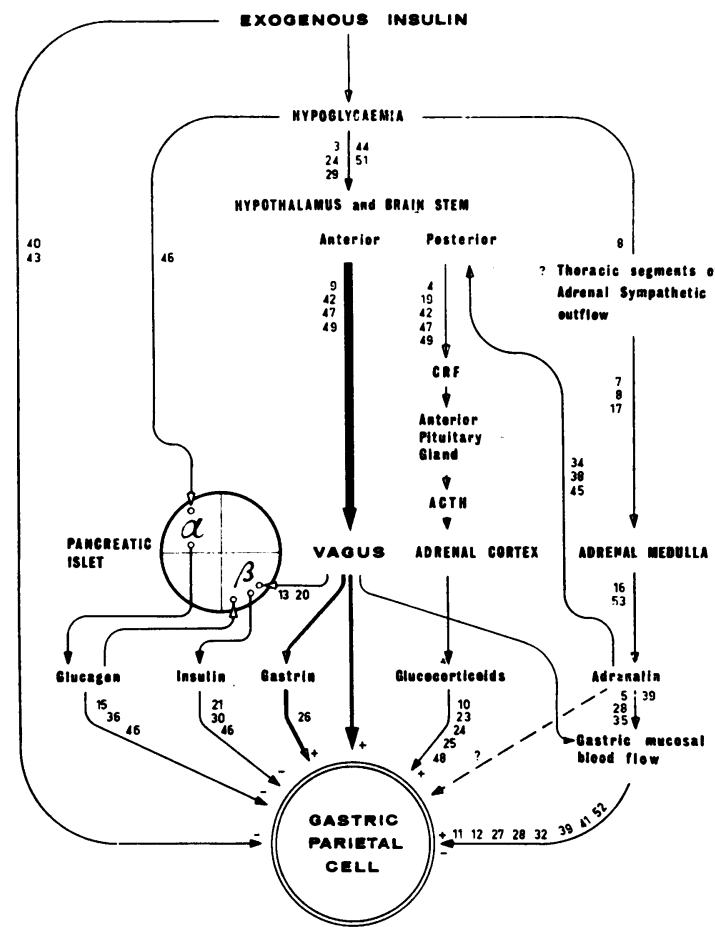

Fig. 3 This diagram shows the possible influences on the gastric parietal cell when hypoglycaemia is induced by exogenous insulin. CRF Corticotropin-releasing factor; ACTH adrenscorticotropic hormone; + stimulation; - inhibition. (The numbers correspond to numbered references in the list of references.)

We are particularly indebted to P.K., S.E., T.C., and L.F. without whom this study could not have been done. We are also grateful to Misses Samantha Hoffman and Margaret Sinclair of the Department of Biochemistry, Royal Perth Hospital, for their technical assistance, and to $\mathrm{Mr}$ N. S. Stenhouse, Director, Raine Medical Statistics Unit, University of Western Australia, for his invaluable help and advice. Professor I. E. Gillespie gave us advice during the preparation of this paper.

References $^{1}$

Abramson, E. A., Arky, R. A., and Woeber, K. A. (1966). Effects of propranolol on the hormonal and metabolic responses to insulin induced hypoglycaemia. Lancet, 2, 1386-1389.

Ahlquist, R. P. (1948). A study of the adrenotropic receptors. Amer. J. Physiol., 153, 586-600.

${ }^{3}$ Bachrach, W. H. (1953). Action of insulin hypoglycemia on motor and secretory functions of the digestive tract.Physiol. Rev., 33, 566-592.

Bachrach, W. H. (1963). On the question of a pituitary adrenal component in the gastric secretory response to insulin hypoglycemia. Gastroenterology, 44, 178-189.

Baronofsky, I., and Wangensteen, O. H. (1945). Erosion or ulcer (gastric and/or duodenal) experimentally produced through the agency of chronic arterial spasm invoked by the intramuscular implantation of epinephrine or pitressin in beeswax. (Abstr.) Bull. Amer. Coll. Surg., 30, 59.

Bell, P. R. F., and Battersby, C. (1968). Effect of vagotomy on gastric mucosal blood flow. Gastroenterology, 54, 1032-1037.

'Cannon, W. B., McIver, M. A., and Bliss, S. W. (1924). Studies on the conditions of activity in endocrine glands. XIII. A sympathetic and adrenal mechanism for mobilising sugar in hyroglycemia. Amer. J. Physiol., 69, 46-66.

${ }^{8}$ Cantu, R. C., Wise, B. L., Goldfien, A., Gullixson, K. S., Fischer, N. and Ganong, W. F. (1963). Neural pathways mediating the increase in adrenal medullary secretion produced by hyfoglycemia. Proc. Soc. exp. Biol. Med., 114, 10-13.

${ }^{\circ}$ Code, C. F. (1951). The inhibition of gastric secretion: a review. Pharm. Rev., 3, 59-106.

${ }^{10}$ Cooke, A. R. (1967). Role of adrenocortical steroids in the regulation of gastric secretion. Gastroenterology, 52, 272-281.

${ }^{11}$ Cumming, J. D., Haigh, A. L.. Harries, E. H. L., and Nutt, M. E., (1963). A study of gastric secretion and blood flow in the anaesthetized dog. J. Physiol. (Lond.), 168, 219-233.

${ }^{12}$ Cutting, W. C., Dodds, E. C., Noble, R. L., and Williams, P. C. (1937). Pituitary control of alimentary blood flow and secretion, the effect of alterations in blood flow on gastric secretion. Proc. roy. Soc. $B, 123,39-48$.

${ }^{13}$ Daniel, P. M., and Henderson, J. R. (1967). The effect of vagal stimulation on plasma insulin and glucose levels in the baboon. J. Physiol. (Lond.), 192, 317-327.

Delaney, J. P., and Grim, E. (1965). Experimentally induced variations in canine gastric blood flow and its distribution. Amer. J. Physiol., 208, 353-358.

${ }^{15}$ Dreiling, D. A., and Janowitz, H. D. (1959). The effect of glucagon on gastric secretion in man. Gastroenterology, 36, 580-581.

${ }^{16}$ Duner, H. (1954). The effect of insulin hypoglycemia on the secretion of adrenaline and noradrenaline from the suprarenal of the cat. Acta physiol. scand., 32, 63-68.

${ }^{17}$ Forrest. A. P. M., and Code, C. F. (1954a). Effect of postganglionic sympathectomy on canine gastric secretion. Amer. J. Physicl. 177, 425-429.

Forrest, A. P. M., and Code, C. F. (1954b). The inhibiting effect of epinephrine and norepinephrine on secretion induced by histamine in separated pouches of dogs. J. Pharmacol. exp. Ther., 110, 447-450.

${ }^{19}$ French, J. D., Longmire, R. L., Porter, R. W., and Movius, H. J. (1953). Extravagal influences on gastric hydrochloric acid, secretion induced by stress stimuli. Surgery, 34, 621-632.

${ }^{20}$ Frohman, L. A., Ezdinli, E. Z., and Javid, R. (1967). Effect of vagotomy and vagal stimulation on insulin secretion. Diabetes, 16, 443-448.

${ }^{21}$ Geziri, M. F., Robertson, C., Plzak, L. F., and Woodward, E. R. (1958). The effect of sympathectomy and adrenalectomy on gastric inhibitory property of insulin. Surgery, 43, 606-609.

Gillespie, G., Elder, J. B., Crean, G. P., Gillespie, I. E., and Kay, A. W. (1970). The short term reproducibility of the insulin response. (Abstr.) Brit. J. Surg., 57, 383.

${ }^{1}$ The numbered references correspond to the numbers in Figure 3. 
${ }^{23}$ Gray, S. J., Ramsey, C. G., and Thorn, G. W. (1956). Adrenal influences on the stomach: peptic ulcer in Addison's disease during adrenal steroid therapy. Ann. Intern. Med., 45, 73-87.

${ }^{24}$ Gray, S. J., and Ramsey, C. G. (1957). Adrenal influences upon the stomach and the gastric responses to stress. Rec. Prog. Horm. Res., 13, 583-617.

${ }^{25}$ Gray, S. J., Ramsey, C., Reifenstein, R. W., and Benson, J. A., Jr. (1953). The significance of hormonal factors in the pathogenesis of peptic ulcer. Gastroenterology, 25, 156-172.

${ }^{26} \mathrm{Grossman}$, M. I. (1968). Physiological role of gastrin. Fed. Proc., 27, $1312-1313$.

${ }^{27}$ Haigh, A. L., Moffitt, J. A., and Steedman, W. M. (1967). The action of a synthetic gastrin-like peptide (I.C.I. 50123) on gastric blood flow and acid secretion in the dog. J. Physiol. (Lond.), 191, 45-46p.

${ }^{28}$ Haigh, A. L., and Steedman, W. M. (1968). The action of catecholamines and adrenergic blockade on gastric blood flow and acid secretion in the dog. J. Physiol. (Lond.), 198, 79-80p.

${ }^{29}$ Hirschowitz, B. I., and O'Leary, D. K. (1964). Dose dependence of insulin-stimulated gastric secretion. Amer. J. Dig. Dis., 9, 379-397.

${ }^{30}$ Hirschowitz, B. I., and Robbins, R. C. (1966). Direct inhibition of gastric electrolyte secretion independent of hypoglycemia or the vagus. Amer. J. dig. Dis., 11, 199-212.

Hollander, F. (1946). The insulin test for the presence of intact nerve fibers after vagal operations for peptic ulcer. Gastroenterology, 7, 607-614.

${ }^{32}$ Jacobson, E. D., Swan, K. G., and Grossman, M. I. (1967). Blood flow and secretion in the stomach. Gastroenterology, 52, 414420.

Karvinen, E., and Karvonen, M. J. (1953). The effect of insulininduced hypoglycaemia on histamine-induced Heidenhain pouch secretion in the dog. Acta physiol. scand., 27, 350-370.

${ }^{34}$ Landon, J., Wynn, V., and James, V. H. T. (1963). The adrenocortical response to insulin-induced hypoglycaemia. J. Endocr., 27, 183-192.

${ }^{35}$ Leonsins, A. J., and Waddell, W. R. (1958). Inhibiting effect of norepinephrine on gastric secretion in human subjects. $J$. appl. Physiol., 12, 334-338.

${ }^{36}$ Lin, T. M., and Spray, G. F. (1968). Effect of glucagon on gastric $\mathrm{HCl}$ secretion. (Abstr.) Gastroenterology, 54, 1254.

Linde, S. (1950). Studies on the stimulation mechanism of gastric secretion. Acta physiol. scand., 21. Suppl. 74. 1-92.

${ }^{38}$ Long, C. N. H., and Fry, E. G. (1945). The effect of epinephrine on adrenal cholesterol and ascorbic acid. Proc. Soc. exp. Biol. (N.Y.), 59, 67-68.
${ }^{39}$ Nicoloff, D. M.. Peter, E. T., Stone, N. H., and Wangensteen, O. H. (1964). Effect of catecholamines on gastric secretion and blood flow. Ann. Surg., 159, 32-36.

${ }^{40}$ Olson, W. H., and Necheles, H. (1955). Primary depression of gastric secretion by insulin in normal man. J. Amer. med. Ass., 159, 1013-1014.

"Peters, R. M., and Womack, N. A. (1958). Hemodynamics of gastric secretion. Ann. Surg., 148, 537-550.

${ }^{42}$ Porter, R. W., Movius, H.J., and French, J. D. (1953). Hypothalamic influences on hydrochloric acid secretion of the stomach. Surgery, 33, 875-880.

${ }^{43}$ Schapiro, H., Cummins, A. J., and Wruble, L. D. (1967). Insulin depression of human gastric secretion. Arch. Surg. (Chic.), 94, 881-883.

${ }^{4}$ Sharick, P. R., and Campbell, D. A. (1951). Gastric secretory response to insulin hypoglycemia-influence of insulin dosage and blood sugar level. Amer. J. med. Sci., 221, 364-368.

${ }^{45}$ Shay, H., and Sun, D.C. H. (1954). Stress and gastric secretion in man. I. A study of the mechanisms involved in insulin hypoglycemia. Amer. J. med. Sci., 228, 630-642.

${ }^{46}$ Singleton, J. W. (1969). Humoral effects of the pancreas upon the gastrointestinal tract. Gastroenterology, 56, 342-362.

'Sircus, W., Huston, C. J. W., Preshaw, R. M., Bassöe, H., and Harkness, R. A. (1963). Studies in dogs on the biphasic nature of the gastric secretory response to hypoglycaemia and other stimuli with special reference to the role of the adrenals. Gut, 4, 42-57.

48Smith, A. W. M., Delamore, I. W., and Williams, A. W. (1961) Gastric acid secretion and mucosal appearances in Addison's disease and hypopituitarism. Gut, 2, 163-167.

49tempien, S. J., French, J. D., Dagradi, A., Movius, H. J., II, and Porter, R. W. (1958). The early and delayed phases of gastric acid secretion in response to insulin hypoglycemia. I. The hypoglycemic secretory responses in duodenal ulcer patients and non-ulcer subjects. II. The hypoglycemic secretory responses in duodenal ulcer patients after vagotomy/pyloroplasty. Gastroenterology, 34, 104-116.

Stokes, B. A. R. (1971). Personal communication.

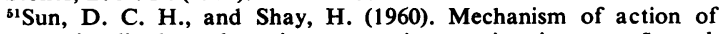
insulin hypoglycemia on gastric secretion in man. J. appl. Physiol., 15, 697-703.

52Thompson, J. E., and Vane, J. R. (1953). Gastric secretion induced by histamine and its relationship to the rate of blood flow. J. Physiol. (Lond.), 121, 433-444.

${ }^{53}$ von Euler, U. S., and Luft, R. (1952). Effect of insulin on urinary excretion of adrenalin and noradrenalin. Metabolism, 1 528-532. 